\title{
UK Popular Music and Society in the 1970s
}

La musique populaire et la société britannique dans les années 1970

John Mullen

\section{(2) OpenEdition}

\section{Journals}

Electronic version

URL: http://journals.openedition.org/rfcb/1695

DOI: $10.4000 /$ rfcb.1695

ISSN: 2429-4373

\section{Publisher}

CRECIB - Centre de recherche et d'études en civilisation britannique

\section{Electronic reference}

John Mullen, «UK Popular Music and Society in the 1970s », Revue Française de Civilisation Britannique [Online], XXII- Hors série | 2017, Online since 30 December 2017, connection on 10 December 2020. URL : http://journals.openedition.org/rfcb/1695; DOI : https://doi.org/10.4000/rfcb.1695

This text was automatically generated on 10 December 2020.

\section{(c) (i) (9)}

Revue française de civilisation britannique est mis à disposition selon les termes de la licence Creative Commons Attribution - Pas d'Utilisation Commerciale - Pas de Modification 4.0 International. 


\title{
UK Popular Music and Society in the 1970 s
}

\author{
La musique populaire et la société britannique dans les années 1970
}

John Mullen

1 Clearly, by definition, popular music stars such as Johnny Rotten, Bob Marley, Joan Armatrading or David Bowie are atypical members of society. Yet the fact that millions of people wanted to listen to, to discuss, or to denounce their musical production suggests that their success can tell us something about society and social change. ${ }^{1}$ Journalists on the hunt for a pithily described zeitgeist often find in popular music fuel for their arguments. Surely the "no Future" Punk rebellion showed mass working class youth anger, Glam rock showed the broadening within society of a more relaxed approach to masculinity and femininity, Reggae the demand of young Black people in Britain for visibility? No doubt all these claims have elements of truth, but oversimplification skulks at every rhetorical corner in such discussions. This is the case not least because of the tremendous variety of personal experience within a mass cultural moment. Only a small minority of the population had Mohican haircuts in 1977: no doubt fewer than those who attended classical musical concerts; reggae, heavy metal or synth rock similarly mobilized minorities. Yet these musical productions were very widely debated, celebrated and denounced, since they were felt to represent values which could structure or damage British ways of living together.

2 The popular music charts do not generally "reflect" or "react" immediately or in any mechanical manner to social change. Much of the artistic sense and structures of feeling of songwriters are formed by long-term developments: we are often led to speak of a "generation" of creators. The tastes, attitudes and priorities of audiences, too, are crystallized over longish periods. Changes not normally directly related to popular culture - such as the abolition of military service at the end of the 1950s, the reduction in the size of families, the fall of the grammar schools, the rise in the number of young people going to university, and the slow return of mass unemployment - are likely to be more influential on audience world views and priorities than one might think. 
This article aims to sketch out some of the main activities and values pertaining to 1970 s popular music at the time it was first listened to. The approach is one of cultural history rather than history of music: the focus is on what large numbers of people did with the music, and what it meant to them, rather than on which artistes influenced which, or on formal innovations within the works produced.

\section{Swinging sixties and creative seventies}

Bertrand Lemonnier, in his article "Musiques et culture pop 1964-70"2 dealing with the previous decade, the 1960s, emphasized the importance of popular music to young people as culture, produced outside the school system, which was exciting and playful and could cater both to feelings of generational revolt and to teenage consumerism. In the 1960s, the generation which had not known the Great Depression or the Blitz was able to express new values, which were more hedonistic and far less parochial. At the same time, singers and songwriters gradually demanded to be taken seriously as artists, and were often felt to be authentic poetic voices of a generation or of a downtrodden or radical group. Pop became more and more rock and proved to be inestimably less ephemeral than its critics had thought it would be.

5 These analyses apply fully to the following decade too, though will need to be added to. Andy Bennett ${ }^{3}$ emphasizes the important stylistic innovations of the 1970s. Indeed, the theatricality of Glam Rock, Heavy Metal or Punk Rock, the virtuosity of much Folk Rock and Progressive Rock and the political expressiveness of Reggae represent just some of the rising phenomena of the period. Bennet regrets that popular music researchers have concentrated almost exclusively on forms of popular music such as "rock" taken seriously by their peers, to the exclusion of studies of equally profitable "pop" groups such as The Sweet or T Rex, or of disco music coming out of Motown in the 1970s. He also insists that the different musical genres were not as hermetic as was often claimed, describing in particular the links between Glam Rock and Punk Rock, despite their differing ethos. Finally, Bennet explains the importance of the tremendous advances in studio technology in the first half of the 1970s, which opened up previously unheard of possibilities. In addition to the technical and theatrical innovations, we shall need to look at the effects of social upheaval on the repertoires and processes of 1970s popular music.

\section{Musical activity}

6 Many scholars who have written on popular music have emphasized that popular music is not just a collection of texts and music, but a series of mass activities in constant flux, reacting to social and technological transformations. What were the main aspects of this in the 1970s? The buying of records was at the centre of popular music culture. Changes in housing and in family size during the post-war boom, as well as a certain prosperity, meant that ever more teenagers had their own bedrooms, equipped with a stereo record player. Internet-based music sharing and streaming were of course several decades off, but the generalization of the cassette recorder allowed sharing of music between friends and to the development of the mix-tape. The high emotions of making a compilation tape for a potential romantic attachment are famously caricatured in Nick Hornby's novel of the 1990 s 
A good compilation tape, like breaking up, is hard to do. You've got to kick off with a corker, to hold the attention (I started with 'Got To Get You Off My Mind', but then realised that she might not get any further than track one, side one if I delivered what she wanted straight away, so I buried it in the middle of side two), and then you've got to up it a notch, and you can't have white music and black music together, unless the white music sounds like black music, and you can't have two tracks by the same artist side by side, unless you've done the whole thing in pairs, and ... oh there are loads of rules. ${ }^{4}$

7 With the rise of the cassette deck, adults could also, for the first time, in the 1970s, listen to music they had chosen in their cars. When not in a car, silence was golden: until 1980 and the marketing of the Sony Walkman in Britain, one could not privately listen to music while walking along the streets, although the marketing of the boombox or "ghetto blaster" in the mid-1970s allowed streetwise youth to listen to and advertise the music they loved.

Radio disc jockeys were becoming more and more influential. BBC Radio, after some decades of considering pop music as an unfortunate phenomenon which should be generally discouraged, had reorganized itself completely in 1967. BBC Radio 1 was set up as a direct response to sharp competition from semi-illegal pirate radio stations which had been broadcasting from ships off Britain's coasts. This new all-popular music station hired disc jockeys from the pirates and was highly successful: in factories, lorry cabs, workshops or sorting offices across the country, the radio was never switched off, and audience participation was ensured by the playing of requests, dedications and pop quizzes. ${ }^{5}$ Star jockeys such as Tony Blackburn (who championed soul music), Dave Lee Travis, ${ }^{6}$ or Noel Edmonds played only new music throughout the day. Annie Nightingale became the first woman radio disc jockey in 1970, and for a long time was the only one. ${ }^{7}$

On the television, the main event of the week was Top of the Pops when the "Top Twenty" of the week was dramatically counted down, and selected groups mimed to their records in the studio. The week's sales became theatre as masses of teenagers speculated, with media help, on what would be next week's number one, and were appropriately disappointed or ecstatic on hearing the result. ${ }^{8}$ Alternatively, the low-budget, late night TV show The Old Grey Whistle Test reflected the tendency to take popular music much more seriously. It concentrated exclusively on album music, fielding quite lengthy live sets, and presented promising newcomers with a TV platform. Aficionados could also follow the specialist music press. The New Musical Express ${ }^{9}$ was no doubt the most influential publication. Founded as early as 1949, it became the best-selling of the music papers during the 1970s, specializing in outspoken and subjective explorations of the new music coming out, an underground tone, and wide ranging interviews with stars or newcomers. Melody Maker, its main competitor, followed close behind. ${ }^{10}$

Collective popular music experiences were changing, too. The local dance hall (often in the Conservative Club or the Liberal Club) where young men would ask women to dance, accompanied by a live band, was rapidly being replaced by the discotheque (in a club, pub or school hall) where records were played. Dancing in couples became less common, ${ }^{11}$ and was sometimes in practice restricted to the last part of an evening. Social mores had changed, single-sex schooling was in sharp decline and opportunities for private contact between men and women were far more common outside dance halls: the need for dance as a courting ritual was less.

The 1970s saw an increase in the number of music festivals in Britain, as well as a change in methods of organizing. The first music festivals we would recognize as such were jazz 
festivals in the 1950s, offering innovative music, holiday freedom and a considerable amount of alcohol. After the legendary Woodstock festival in the USA in 1969, free festivals were organized in Britain, such as the Glastonbury Free Festival in 1971. Their free status corresponded with the ethos of young people at the time, though of course they also helped sell records and popularize artistes. The Isle of Wight festival (in 1968, 1969 and 1970) was no doubt the first one that aimed at being commercially viable. "We were uncool because we weren't free" said one organizer ${ }^{12}$ but 600000 people came in 1970, to hear US artistes such as Jimi Hendrix and Joan Baez, but also The Who, The Moody Blues and Emerson, Lake and Palmer. The Reading festival, which in the 1960s had featured first jazz and later rock, was the first major festival to embrace punk rock, towards the end of the decade. Just as in the sixties there had sometimes been brawls between fans of trad jazz and those of modern jazz, punks and other rock fans sometimes fought it out at Reading.

This occasional violence underlines the fact that the 1970s continued to see flourish modes of group identification through music which had emerged in the previous decade or two. If the 1960s saw its mods and rockers defending contrasting values, the 1970s saw several musical genres generate "subcultures": punks, skinheads, and heavy metal fans to name just three. ${ }^{13}$ Clothing and aesthetic and social values were closely associated. Exclusivity was often in evidence: it was difficult, socially, to like both punk and disco music in the late seventies, for example. Occasionally violent conflict could emerge; more commonly, a theatrical representation of violent intent on the concert stage was sufficient.

The Punk Rock subculture may have been the one which involved the most varied activities. Punk resembled an earlier trend from the 1950s - skiffle - in its Do It Yourself aesthetic. The recommended activity in the punk milieu was not to dance away a Saturday night, but to form one's own band and express anger and criticism. Just as in the fifties hundreds or perhaps thousands of (often-shortlived) bands were formed, so for a few years after 1976 it seemed "everybody", or at least all young male high school students, were in a punk or post punk band of some sort. Punk rock also popularized the fanzine: the simply produced music magazine put together by amateurs to discuss punk rock, politics and other questions. Younger readers should not underestimate the amount of work involved in this in this time before computers or even photocopiers were widely available. Manchester punk band The Buzzcocks came up with the idea, revolutionary at the time, of funding their own record instead of trying to persuade a record company to give them a contract, thus setting off a tsunami of small independent record companies which would permanently transform the UK music industry.

\section{Musical genres}

14 To examine the many thousands of popular songs of the decade, one is obliged to break them down into genres according to the style of music, or the values expressed. We habitually speak of such genres as Glam Rock, Progressive Rock, Folk Rock, Punk, Reggae, Metal or Synth Pop, yet the contours of a genre are not clearly delineated, are often fiercely debated, and the genres themselves may be useful journalistic labels rather than based on solid commonalities. In addition, many songs do not fit neatly into any genre. ${ }^{14}$

Glam Rock featured flamboyant or androgynous dressing and texts about love and partying. ${ }^{15}$ The names of many stars - Wizzard, The Sweet, ${ }^{16}$ The Glitter Band, Alvin 
Stardust - translate the atmosphere. David Bowie and Queen moved through, then transcended, this genre to gain lasting recognition. The theatrical flamboyance of Glam Rock went further in individual self-expression than the Rock and Roll of the 1960s, and the ambiguous sexualities sometimes celebrated were part of a longer trend to wider bounds of acceptability. Anecdotal evidence suggests that the productions of artistes such as Bowie were tremendously helpful in spreading the message that one might have more choice about how to live one's gender than staid society had suggested. Large numbers of (mostly secretive) gay people, in particular, felt options opening up.

Metal, known at the time as Heavy Metal, continued a tradition of theatricality in popular music, with the most celebrated players, Black Sabbath, ${ }^{17}$ Deep Purple and Judas Priest, still well-known today. Musically, the genre was characterized by much higher volume than was traditional, emphatic, jerky rhythm, and an original use of voice. Themes were generally dark: Satanism, drug taking, war and sadomasochism were very much present. Black Sabbath's "Killing Yourself to Live" or Judas Priest's "Screaming for Vengeance" are not atypical:

Screaming, screaming for vengeance

The world is defiled in disgrace.

Tie a blindfold all around your head

Spin you 'round in the torture before the dread.

And then you're pushed and shoved into every corner

Then they lead you out into the final slaughter.

Following in the tradition of rock and roll, Motorhead penned a song to the glory of the genre they were part of, and more particularly in praise of high volume music:

Only way to feel the noise is when it's good and loud

So good I can't believe it, screamin' with the crowd

Don't sweat it, get it back to you

Don't sweat it, get it back to you

OVERKILL, OVERKILL, OVERKILL

Metal music, themes and dress-codes, then, appealed to a desire for aesthetic rebellion against upbeat, ambitious, optimistic, smartly dressed, establishment ways of life.

Those artistes grouped together under the genre label "Progressive Rock" wanted to carry on the tendency set into motion by Bob Dylan and by the later Beatles, of taking popular music seriously as art. Sometimes classically trained, these groups ${ }^{18}$ recorded longer pieces, wanted coherent "concept albums" to be at the centre of their work, and eschewed the sexually boastful on-stage presence which had been part of the rock $\mathrm{n}$ roll experience. Led Zeppelin's 8-minute song "Stairway to Heaven" is one of the most celebrated pieces, combining, typically for the genre, a dreamy atmosphere with philosophical lyrics:

There's a lady who's sure all that glitters is gold

and she's buying a stairway to heaven.

When she gets there she knows

If the stores are all closed

With a word she can get what she came for. ${ }^{19}$

Jethro Tull's Thick as a Brick album (1972) is another key example. Prog rock albums of this sort had some claim to contain "rock poetry". The turn in British poetry to more accessible and popular work, with the Liverpool poets ${ }^{20}$ and with Adrian Mitchell and others, went in parallel with the production of rock lyrics of a poetic nature, whether in progrock or elsewhere. 
Really don't mind if you sit this one out

My words but a whisper, your deafness a shout

I may make you feel but I can't make you think

Your sperm's in the gutter, your love's in the sink.

So you ride yourself over the fields and

You make all your animal deals and

Your wise men don't know how it feels

To be thick as a brick.

21 tools in addition to text), lyrics had obviously moved a long way since the early Beatles' hits "I wanna hold your hand" or "She loves you, yeah, yeah, yeah". This shift was not restricted to progressive rock. Folk rockers like Richard Thompson or post-punk singers like Elvis Costello are two of many who have some claim to be poets.

Oh I used to be disgusted

And now I try to be amused.

But since their wings have got rusted,

You know, the angels wanna wear my red shoes.

But when they told me 'bout their side of the bargain,

That's when I knew that I could not refuse.

And I won't get any older, now the angels wanna wear my red shoes.

Progressive rock, according to Edward Macan, author of one influential study "attempted to bridge the gulf between high and low culture", ${ }^{21}$ though it was also considered guilty at times of self-absorption, of elitism and of melodrama.

Folk music had undergone a grassroots revival in the 1960s with the gradual establishment around the country of hundreds of folk clubs where enthusiasts would gather, and where "authenticity", real ale and bonhomie were far more important than stardom and virtuosity. The clubs felt themselves to be enjoying real "people's music" somewhat distant from the pop music industry, though there may have been more teachers than blue-collar workers present. ${ }^{22}$

In record sales, a niche market had been established with bands such as Fairport Convention, Pentangle, The Dubliners or The Chieftains, often playing a mix of traditional rural songs (about courtship or the passing of the seasons, witchcraft or village life $\mathrm{fe}^{23}$ ) and newly composed pieces. In the 1970s, Richard Thompson and others moved into folk rock. ${ }^{24}$ After the arrival of punk rock, The Pogues would mix the high speed rock sounds with traditional Irish repertoires and Runrig ${ }^{25}$ would eventually produce Scottish folk rock in huge stadiums.

Reggae, which had come to 1960s Britain from Jamaica, had initially been limited to West Indian communities in the bigger towns. Its texts in Jamaican dialect, rebellious attitude and bass-dominated beat had represented for young British West Indians something of their own in these times before multicultural education. It then became popular among white youth counter-cultures such as mods and early skinheads. The 1970s was the decade it moved into the mainstream, symbolizing the desire of young West Indians to be publicly part of British life on their own terms, and their rejection of their parents' deferential attitudes to the "Mother country".

Reggae had some difficulty getting this mainstream acceptance: for a long-time it was not played on the radio, where deciders were solidly white. Home-made sound systems got the music onto the streets at the Notting Hill Carnival, at informal house parties and elsewhere. The first Reggae Number One in Britain was Desmond Dekker's The Israelites in 
1969. ${ }^{26}$ The song spoke of poor Black people working to feed their family, and used the Rastafarian comparison of the African Diaspora to God's chosen Israelites in the Old Testament, who will one day be delivered from exile. Bob Marley's work made reggae universally known: his album Catch a Fire in 1973 was his first hit album in the UK, and Exodus (1977) perhaps the most influential. Aswad (formed in 1975) and the more political Steel Pulse ${ }^{27}$ (formed the same year) were the most successful of the bands formed by UK born descendants of West Indian families.

A minority opinion criticized the mainstreaming of reggae, feeling that an authentic Jamaican music was being diluted and commercialized for the profit of dominant groups. Jamaican reggae artiste Macka B in a 1990 song complained about the highly successful band UB $40 .^{28}$

They nu want gi we credit fi we invention

Reggae music invent by the Jamaican

UB40 tek it and a make the most million ${ }^{29}$

While Mike Alleyne developed a research-based critique in particular of the work of Bob Marley:

Marley's market impact was not simply the logical result of an intangible synthesis of charisma, performing talent, creative passion and divine inspiration. These factors would have been of little significance without the careful tailoring of audio and visual texts to fit audience biases and record-label market preconceptions. Marley's first Island Records release, Catch a Fire, (1972) , features a treble oriented mix and rhythm tracks accelerated in postproduction to attract the rick audience [...] The commercially motivated dilution of a core element is alarming at the very least, and raises serious questions regarding authenticity and integrity. ${ }^{30}$

This polemic is not untypical of several others concerning the "ownership" and policing of different popular music genres and subcultures, polemics which have while away thousands of evenings among friends in the pubs of Britain. The working-class nature (or not) of punk rock was another such polemic, and whether or not a given group was "really " punk has produced many hours of discussions not dissimilar to medieval theological debates.

Indeed, Punk rock seemed at the time absolutely anti-establishment, but it is in the nature of popular cultural genres to be partially incorporated. No punk rockers have yet been knighted, but the British Library presented in 2016 an exhibition on punk rock, and the most emblematic punk star, Johnny Rotten of the Sex Pistols could be found in 2008 appearing in adverts for the British butter brand, Country Life.

31 From a purely musical point of view, punk rock did not bring much innovation apart from an accelerated rhythm, a prominence for the drums and a preferring of rapid start-up in a song to gradual build-up. Its main contribution lay elsewhere. Punk's emergence in 1976 was an aesthetic response to the social and political crisis. Born in the art schools, it rapidly gained popularity among working class youth.

The typical narrator from a rock and roll song was the young man sure of his success with the girls, that of progressive rock the spiritual ascetic poet. The punk narrator is often a bitter, sarcastic loser, and sarcasm in popular music had before that time been very rare. The Sex Pistols songs "Pretty Vacant" and "God Save the Queen" are the most iconic examples. The genre reacted against sophisticated and overlong virtuoso prog rock productions and against cheerful disco dancing hits to sing instead a grittier malaise. Although musical genres do not mechanically reflect the period they are produced in, it 
would be difficult to imagine Punk's "No Future" aesthetic in the 1950s, when almost everyone felt the society's prospects were rosy.

Punk's Do It Yourself ideology spawned thousands of local bands, and the rise of the amateur fanzine and the small independent record label. Even those bands who signed with bigger companies often tried to work against the excesses of commercialism. Crass ${ }^{31}$ printed on their single covers "Do Not Pay more than 45 pence", whereas the Clash's triple album, Sandinista (1980), was deliberately sold for the price of an ordinary album.

Punk seemed to open the gates to dealing with a much wider variety of themes in popular song, with a particular emphasis on the gritty. So masculine rivalry seen from the perspective of a loser ${ }^{32}$ Northern Irish politics, ${ }^{33}$ personal independence, ${ }^{34}$ parental pressure for success, ${ }^{35}$ or women's body image in society, ${ }^{36}$ and many dozens of other topics were dealt with. Interestingly, punk opened up space for female groups, and singer-songwriters, as we shall see below.

In the last few years of the decade, the Synth pop genre emerged. Partly inspired by the German group Kraftwerk, this genre was aiming not at exploring new kinds of lyrical content or theatrical communication, but on producing new sounds, with the different kinds of synthesizer newly available commercially, or rigged up from spare parts by enthusiasts. Tubeway Army ${ }^{37}$, Ultravox ${ }^{38}$ and The Human League ${ }^{39}$ were important names. Their songs tended to glorify the mysterious electronic future and leave sarcasm and social comment behind.

This brief overview of 1970s musical genres should also be seen in the context of developing production technology. If Punk mostly eschewed sophisticated studio reworkings, others did not. Andy Bennett gives two examples, but there are many more:

'Studio' bands of the 1970s, such as $10 \mathrm{cc}^{40}$ or Steely Dan ${ }^{41}$ set new benchmarks for song writing and production, utilizing the full potential of the studio to produce albums of highly diverse material and in some cases featuring special studio-crafted effects and soundscapes that remain unique to this day. ${ }^{42}$

Indeed, in the 1970s, the studio became ever more a creative element in itself. Developing technology and the generalization of stereo sound led artistes to put much effort into " aural staging". A flute can be made to sound near or far, still or moving, can be made to sound as if it is playing in a warehouse or in a living room. Studio production allowed one to choose separately the aural staging of each voice and instrument, or to change the staging from one minute to the next. ${ }^{43}$

\section{Men and women}

The popular music industry of the 1970s appears to have been male-dominated from top to bottom, whether one looks at songwriters, instrumentalists, radio disc jockeys or composers. Only as singers and dancers was there much space for women. This is not to say the female minority was not significant. Kate Bush ${ }^{44}$ Joan Armatrading ${ }^{45}$ Christine McVie (of Fleetwood Mac), Siouxsie (of Siouxsie and the Banshees) ${ }^{46}$ wrote songs wellknown in the mainstream. Sandy Denny wrote and sang some of the milieu's favourite folk and folk-rock songs. ${ }^{47}$ Poly Styrene, the mixed-race female singer-songwriter of Punk band X-Ray Spex was another notable exception. The slits and the Raincoats found success as two all-women post punk bands. The former's production included sarcastic lyrics about being a woman in modern society: 
Typical girls are looking for something

Typical girls fall under spells

Typical girls buy magazines

Typical girls feel like hell

Typical girls worry about spots, fat, and natural smells.

[...]

Don't create, Don't rebel

Have intuition, Don't drive well sung about dancing on a Saturday night and about meeting a potential lover or mate. It is not surprising, though, that in a decade with much social upheaval, politics forged a considerable repertoire. This would merit an article in itself, but we can only touch on it here. Subjects such as racism, which affect more directly young people, before they enter the workforce, than do questions of industrial relations or international policy, were the most dealt with. ${ }^{49}$ We have seen above some songs about sexism. Gay oppression was sung about occasionally, both by such highly political artistes as Tom Robinson, and by more mainstream performers like Rod Stewart. ${ }^{50}$ The Kinks defended a positive attitude to cross-dressing in "Out of the Wardrobe" in 1978. The conflict in Ireland, (although the British population was often very badly informed about it), produced a number of pieces, ${ }^{51}$ while Peter Gabriel's "Biko" denounced the savagery of apartheid in South Africa. Many songs dealing with young people's experience of life also have a political tint, such as John Lennon's "Working Class Hero" from 1970, The Boomtown rats "Rat Trap" from 1978 or Pink Floyd's "Another Brick in the Wall" from 1976.

The "message" of political songs is not usually about transmitting information (most listeners have heard the song before, and many of the opinions contained are already agreed by the audience). Popular songs are meant to be listened to many times, and singing along, out loud or silently, is an important part of the experience. It is useful to see songs as a form of participative theatre. The listener (who may be singing along) is asked for a few minutes to imagine that they are the narrator, the singer, or both. Political songs can, then, encourage the listener to play the role of political commentator, suffering victim, powerful rebel and many other roles. Occasionally the singer (and listener) play the role of the oppressor, in ironic songs such as "Sorry Mr. Harris" by the Tom Robinson Band, whose lyrics include:

I'm sorry if the soldiers have to hurt you, Mr Harris

You haven't really left them any choice

This must be quite a trial

You haven't eaten for a while

I wonder what's the matter with your voice?

If you told us what you know it might be wiser

No need to knock your head against a wall 
If you told us who you know it might be wiser

I think it might be better for us all share of the vote: up to $30 \%$ in a few towns. ${ }^{53}$ The spark which led to the rise of Rock against Racism was the reaction by a group of left wingers to Eric Clapton's drunken racist tirade at a concert in Birmingham. A letter to the music press brought hundreds of replies, and the network became much more powerful than its initiators had thought possible. In the following months, dozens of local concerts were organized following the RAR recipe: black reggae groups and white punk groups playing on the same bill, the black group always top of the bill. The result was both the mixing of musics, as different influences met each other, and the mixing of different audiences which up to then had been subject to de facto unthinking racial segregation : reggae music had been for Blacks and punk music for Whites. ${ }^{54}$ National events were also organized, in conjunction with the Anti-Nazi League, an activist network dedicated to stopping fascist meetings and countering their ideas. In Spring 1978, a march followed by a mass free concert at Victoria Park in Hackney drew over a hundred thousand people, and featured The Clash, steel Pulse, and many others. 

independent record labels, which accidentally appeared at the same time as Rock against Racism, gave some ideal tools to a grassroots campaign of this sort. The success or otherwise of such a movement is extremely difficult to measure, though many participants were convinced of its tremendously positive effects. "Without Rock against Racism London would not be the multicultural capital of Europe today" declared one speaker in a recent forum in London. ${ }^{55}$

\section{Conclusion : rupture and continuity.}

The Seventies saw a continuous rise in the amount of music in most people's lives, with the generalization of all-music radio, and increasing cultural freedom and spending power among teenagers. As in the Sixties, much popular music was playful, exciting and oppositional; perhaps the melodramatic tone was on the rise, whether in heavy metal, punk, or reggae. The three minute rock song continued to dominate though supplemented by some longer pieces. Popular music took itself and was taken more seriously.

It is perhaps not surprising that a decade so much characterized by social and political crisis should be a fruitful one as far as popular music is concerned. Popular music was a multi-billion-pound industry, but it was also a series of repertoires and processes which people, and particularly young people, felt belonged to them in a way that other creative endeavours, taught in schools or conservatories, did not. These popular musics, then, could be used to express their priorities and not only to build careers and pay back shareholders. Punk songwriters, Reggae songwriters, and others, had much to say to the audiences they designed and who adored them. Though the multiplicity of popular music and the many factors influencing its content make societal analysis notoriously risky, the fact that it meant so much to so many millions of people make its study essential for the historian. ${ }^{56}$

John Mullen est professeur en civilisation britannique à l'Université de Rouen. Il est directeur de publication de la Revue française de civilisation britannqiue et viceprésident du CRECIB. Il a publié de nombreux écrits sur l'histoire de la musique populaire britannique, dont le livre The Show Must Go On - la Chanson populaire en Grande Bretagne pendant la Grande Guerre (L'Harmattan 2012).

\section{BIBLIOGRAPHY}

ALLEYNE, M. “White Reggae : Cultural Dilution in the Record Industry, Popular Music and Society $24: 12000$

BENNETT, A., “The Forgotten Decade : Rethinking the Popular Music of the 1970s," Popular Music History, 2:1, 2007.

BLACKMAN, R. “Rock and Roll against Racism”, Socialist Review January 2016

Revue Française de Civilisation Britannique, XXII- Hors série | 2017 
CLARKE, G. J., HALL, S., JEFFERSON, T. and ROBERTS, B. "Subcultures, Cultures and Class. A Theoretical Overview" in S.HALL and T. JEFFERSON (eds) Resistance through Rituals: Youth Subcultures in Post-war Britain, London, Hutchinson, 1976.

FAST, S. “'Stairway to heaven', myth, epic ritual” in Marc WOODWORTH and Ally-Jane GROSSAN (Eds), How to Write about Music, New York, Bloomsbury Academic, 2015.

GREIL, M. In the Fascist Bathroom: Punk in Pop Music, 1977-1992, Harvard, Harvard University press, 1999.

HEBDIGE, D., Subculture: the Meaning of Style, London, Methuen, 1979.

LEMONNIER, B.; “Musiques et culture pop 1964-70", Revue française de civilisation britannique X:1 , 1998

LONG, P. The History of the NME, London, Portico, 2012

MACAN, E., Rocking the Classics: English Progressive Rock and the Counterculture, Oxford, Oxford University Press, 1997.

MACKINNON, N; The British Folk Scene: Musical Performance and Social Identity, Maidenhead, Open University Press, 1993.

MULLEN, J. “ ‘I hope I die before I get old!’ : Légitimité, identité et authenticité dans la musique populaire britannique", RANAM n $39,2006$.

STRINATI, D., An Introduction to Theories of Popular Culture, New York: Routledge, 2004.

TAGG, P., Music's Meanings, New York, Mass Media Music Scholars Press, 2012

\section{NOTES}

1. Note on musical sources: I have not included in the footnotes internet addresses for listening to the many songs and albums I reference. Almost all of them are easily available on YouTube.

2. Bertrand Lemonnier, "Musiques et culture pop 1964-70", Revue française de civilisation britannique X:1, 1998.

3. Andy Bennett, "The Forgotten Decade : Rethinking the Popular Music of the 1970s" in Popular Music History, 2:1, 2007.

4. Nick Hornby, High Fidelity, New York, Riverhead, 1995, p. 89.

5. A short unofficial but useful history of the channel can be found at http:// www.radiorewind.co.uk/radio1/history_of_radio_1_details.htm

6. Dave Lee Travis was responsible, in 1976, for a parody pop song, "Convoy GB", which can be found on YouTube.

7. Progress was slow but by 2016, Radio 1 was celebrating International Women's Day by having only-female presenters all day long http://www.bbc.co.uk/diversity/newsandevents/BBCRadio-1-all-female-DJ-line-up-for-two-nights-celebrating-International-Womens-Day

8. This despite recurrent accusations of chart fixing, explained quite convincingly by ITV's world in action documentary in 1979 https://www.youtube.com/watch?v=VQ2x2gbYUgg

9. The publication still exists http://www.nme.com/

10. Melody Maker was published from 1926 to 2000.

11. French readers might want to note that dancing to rock and roll songs as a couple was already well on its way to extinction in the 1970s UK.

12. Interviewed in the BBC documentary Festivals Britannia, BBC, 2010.

13. Dick Hebdige, Subculture: the meaning of style, London, Methuen, 1979. 
14. I recommend Lieutenant Pigeon's “Mouldy Old Dough”, for example.

15. Slade's "Cum on Feel the Noize" or Mud's "Tiger Feet" are fair examples.

16. See their song "Ballroom Blitz".

17. Black Sabbath's second album, Paranoid (1970), can be heard on YouTube.

18. Pink Floyd, Genesis, Yes, Jethro Tull, Led Zeppelin, ELP and King Crimson are among the most commonly cited.

19. Susan Fast skilfully analyzes the link between the lyrics and the music in this piece in Susan Fast, “'Stairway to heaven', myth, epic ritual” in Marc Woodworth and Ally-Jane Grossan (Eds), How to Write about Music, New York, Bloomsbury Academic, 2015.

20. The Mersey Sound, an anthology of poems published in 1967 by Adrian Henri, Brian Patten and Roger McGough (Penguin, Harmondsworth) went on to be one of the best-selling anthologies of all time.

21. Edward Macan, Rocking the Classics: English Progressive Rock and the Counter-culture, Oxford University press, 1997, p. 222.

22. A fascinating sociological study is available in Niall MacKinnon, The British Folk Scene: Musical Performance and Social Identity. Maidenhead, Open Univ Press, 1993.

23. Steeleye Span's “The Blacksmith” for example.

24. Steeleye Span, A Parcel of Rogues (1973); Fairport Convention, Tippler's Tales (1978).

25. The Highland Connection (1979).

26. The second was from one-hit wonder Althea and Donna, "Up Town Top Ranking" in 1977.

27. Their albums included Handsworth Revolution (1978) and Tribute to the Martyrs (1979).

28. Formed in Birmingham in 1978 by a mixed-race group of friends, UB40 became one of the best-known British bands of their time. See their debut album Signing off (1980).

29. Macka B. (1990). Blackman. On Natural Suntan [LP]. London: Ariwa.

30. Mike Alleyne "White Reggae: Cultural Dilution in the Record Industry, Popular Music and Society, $24: 12000$.

31. Stations of the Crass (1979).

32. The Jam, "David Watts" (a cover of a Kinks song).

33. Stiff Little Fingers, "Alternative Ulster".

34. The Buzzcocks "Autonomy".

35. XTC "Making Plans for Nigel".

36. Crass "Shaved Women".

37. Their first album, entitled Tubeway Army, was released in 1978.

38. Their first album was Ultravox! in 1977.

39. Their first album was Reproduction in 1979.

40. See, among their albums 10cc (1973), Bloody Tourists (1978)

41. A US band.

42. Bennet, Op. Cit., p 7.

43. For a more detailed presentation of such tools, see Philip Tagg, Music's Meanings, Mass Media Music Scolars Press, 2012, chapter 8.

44. See her debut album The Kick Inside from 1978.

45. See her debut album Whatever's for Us from 1978.

46. See their debut album The Scream from 1978.

47. See her first solo album The North Star Grassman and the Ravens from 1971.

48. Marcus, Greil, In the Fascist Bathroom: Punk in Pop Music, 1977-1992, Harvard University press, Harvard, 1999, p. 113.

49. There are many examples, such as Steel Pulse's "Klu Klux Klan" (1978).

50. "The Killing of Georgie” 1976. 
51. Of which three examples will suffice: Paul McCartney's "Give Ireland back to the Irish", written shortly after Bloody Sunday and banned by BBC radio; Paddy McGuigan "The Man behind the wire", 1975 ; Stiff Little Fingers "Alternative Ulster", 1978.

52. Socialist Review, January 2016.

53. One can watch online a documentary by the award-winning World In Action on the British fascists in the late 1970s. the documentary was made in 1978 and is available here: https:// www.youtube.com/watch?v=yNalu0pSL2A

54. With a small number of notable exceptions such as mixed race woman singer Poly Styrene from the punk group X ray Spex.

55. "How is Racism Changing in Britain" Hassan Mahamdallie, Institute of Education, London, 1st July 2016.

56. My thanks to Andy Hill, Sylvestre Jaffard and Dave Sewell for handy references provided.

\section{ABSTRACTS}

Commentators are unanimous about the important role of the UK in the 1970s in the history of popular music. Black Sabbath, Led Zeppelin, David Bowie, the Sex Pistols and the Police : perhaps no other country produced as many influential artistes in this decade. Yet there has generally been a separation between "serious" historical analyses of the decade's social history and examinations of its musical legacy. This article attempts to look at the music in connection with the history of British society. What was changing about people's relationship to music? What were artistes proposing to consumers, as entertainment, as philosophical or political discourse or as aesthetic rebellion?

Les commentateurs sont unanimes concernant le rôle important qu'a joué le Royaume-Uni des années 1970 dans l'histoire de la musique populaire. Black Sabbath, Led Zeppelin, David Bowie, les Sex Pistols, Police: quel autre pays a produit autant d'artistes influentes durant cette décennie ? Pourtant il y a souvent eu séparation entre les analyses « sérieuses » de l'histoire de la société et les examens de la musique qu'elle nous a léguée. Cet article est une tentative de voir la musique dans le contexte de l'histoire sociale. Quels changements étaient en cours concernant le rôle de la musique dans la vie quotidienne? Que proposaient les artistes aux consommateurs, comme divertissement, comme discours philosophique ou politique, comme rébellion esthétique?

\section{INDEX}

Mots-clés: musique, musique populaire, punk, identité, jeunesse

Keywords: music, popular music, 1970s, rock, identity, subcultures, Glam rock, punk rock

\section{AUTHOR}

\section{JOHN MULLEN}

Université de Rouen, ERIAC 